\title{
2030 Agendako helburuetatik lurra-ura hartzera
}

\section{(From Agenda 2030 goals to land-water management)}

\author{
Ane Zabaleta*1, Eñaut Izagirre $^{1,2}$, Maite Meaurio ${ }^{3}$, Maria Valiente $^{1}$, \\ Jesus Angel Uriarte ${ }^{1}$, Iñaki Antiguedad ${ }^{1}$ \\ ${ }^{1}$ Hidro-Ingurumeneko Prozesuak ikertaldea, Geologia Saila, \\ Euskal Herriko Unibertsitatea UPV/EHU \\ ${ }^{2}$ Basque Centre for Climate Change BC3 \\ ${ }^{3}$ Hidro-Ingurumeneko Prozesuak ikertaldea, Kimika Aplikatua Saila, UPV/EHU
}

\begin{abstract}
LABURPENA: Garapen Iraunkorrerako 2030 Agendaren hiru dimentsioei (ekonomikoa, soziala eta ingurumenarena) lurraldearena gehitu behar zaie, ekintza-planak gauzatzeko ezinbesteko ingurune fisikoa baita. Hortik dator hidrologiatik ari garen ikertzaileok iraunkortasunari egin diezaiokegun ekarpena: ura eta lurra uztartuta lurralde dinamikoak erresiliente egiteko bidean ezagutza sortzea, erabakietan eragiteko. Iraunkortasuna zutabe hartuta, uraren kudeaketan ohikoa den ibai-ikuspegia aldatu eta arro-ikuspegia ezarri beharra dugu, eta ibai-arroa (ura + lurraldea) lurralde-antolamenduaren oinarrizko unitate biofisiko bihurtu. Hala, klima-aldaketaren aurrean ezartzen diren arintze- eta egokitze-politiken bateragune bihurtzen da ibai-arroa, bi estrategia horien arteko sinergiak eta helburu-gatazkak identifikatzea errazten duen heinean. Izan ere, klima-aldaketarekin lotutako mundu mailako arintze-politiken oinarriak karbonoa bahitzea eta horri lotuta lurraldea basotzea dira neurri handi batean, basotzeak klima-aldaketara egokitzeko ekar ditzakeen albo-kalteak kontuan izan gabe. Lurraldearen funtzio hidrologikoek eragina dute uraren kantitatean, kalitatean, kokapenean eta denboran, zeren eta ura metatzen, mugitzen eta eraldatzen baitute. Beraz, lurraldeak uraren erregulatzaile gisa duen funtzioa onartuz gero, baliabide hidrologikoen kudeaketa ulertzeko modua aldatuko litzateke, baita egokitzera bidean lurraldearen kudeaketan zerbitzu hidrologikoak barneratzea erraztuko ere. Horretarako, beharrezkoa da tokiko eskalari lotutako ezagutzen eta helburuen arteko gatazkak eta sinergiak zein diren jakitea. Alde horretatik, bizi dugun ziurgabetasun-aroan, auzi horiek argitzera bideratu behar genituzke ikerketa-bide nagusiak, haiek egoki kudeatzeko eta ezagutzak informatutako erabakiak hartzeko, ohiko inertziak gaindituta, kudeaketa-paradigma aldatuta. Hortaz, lurralde-dinamikak birbideratzeko borondate soziopolitikoa behar da, eta naturak lekuan-lekuan eskaintzen dituen zerbitzu ekosistemikoen mugetara egokituriko garapen-eredu bat barneratu, lurra eta ura lurraldearen ardatzean jarrita, munduko edozein herrialdetan.
\end{abstract}

HITZ GAKOAK: ura, lurraldea, iraunkortasuna, egokitzea, helburu-gatazkak (trade-offs).

ABSTRACT: The 2030 Agenda includes objectives in three dimensions (economic, social and environmental). To these three, we must add the territory where the action plans are implemented. Hence, as researchers working in hydrology we must generate knowledge towards the resilience of dynamic territories combining Water and Land. Thus, this article analyses the need to establish a basin-perspective in water management instead of the usual river-perspective, considering the basin as the basic bio-physical unit for territorial planning. Climate change mitigation and adaptation policies converge in the basin, facilitating the identification of synergies and trade-offs between both strategies. In fact, global mitigation policies focus, largely, on carbon sequestration through reforestation, neglecting its side-effects on adaptation. The hydrological functions of the territory affect the quantity, quality, location and timing of water, by accumulating, moving and transforming it. Therefore, accepting this water regulatory function would imply a change in the way of understanding the management of water resources and an improvement in the integration of hydrological services in the territorial planning. For this purpose, local knowledge and knowledge on trade-offs and synergies between different objectives are needed. In this era of uncertainties, we should focus our main research strategies towards minimization of uncertainties in order to properly manage them and make knowledge-informed decisions, thus, changing the management paradigm. We need, therefore, socio-political will to redirect territorial dynamics, incorporating a development model adapted to local ecosystem services limitations, placing Land and Water in the centre of the territory, anywhere in the world.

KEYWORDS: water, territory, sustainability, adaptation, trade-offs.

* Harremanetan jartzeko / Corresponding author: Ane Zabaleta, Hidro-Ingurumeneko Prozesuak ikertaldea, Geologia Saila, Zientzia ea Teknologia Fakultatea, Euskal Herriko Unibertsitatea UPV/EHU, Sarriena, z/g (48940 Leioa, Bizkaia). ane.zabaleta@ehu.eus - https://orcid.org/0000-0003-1495-8968.

Nola aipatu / How to cite: Zabaleta, Ane; Izagirre, Eñaut; Meaurio, Maite; Valiente, Maria; Uriarte, Jesus Angel; Antiguedad, Iñaki (2021). "2030 Agendako helburuetatik lurra-ura hartzera»; Ekaia, ale berezia 2021, 229-246. (https://doi.org/10.1387/ekaia.22113).

Jasotze-data: 2020, urriak 06; Onartze-data: 2021, azaroak 09

ISSN 0214-9001 - elSSN 2444-3255 / (c) 2021 UPV/EHU

(i) (-) $\odot$ Lan hau Creative Commons Aitortu-EzKomertziala-LanEratorririkGabe 4.0 Nazioartekoa

lizentzia baten mende dago 
Ane Zabaleta, Eñaut Izagirre, Maite Meaurio, Maria Valiente, Jesus Angel Uriarte, Iñaki Antiguedad

\section{SARRERA}

«Gure mundua eraldatzea: 2030 Agenda garapen iraunkorrerako» ${ }^{1}:$ horra Nazio Batuen Erakundeak (NBE) 2015ean argitara emandako txostenaren izenburua [1]. Berez, «pertsonen, planetaren eta oparotasunaren aldeko ekintza-plana da», eta helburua gaur «munduak duen erronkarik handiena» erdiestea da, hau da, garapen iraunkorra, eta pobrezia amaitzea, horretarako «neurri ausartak eta eraldatzaileak» hartu eta «mundua iraunkortasunaren eta erresilientziaren bidetik birbideratzeko». Hau da, iraunkortasuna helburu eta helbide.

Garapen iraunkorrerako bidea jorratzeko, 17 helburu (GIH) eta 169 erronka biltzen ditu 2030 Agendak, 2015-2030 tarterako, «integratuak eta banaezinak, garapenaren hiru dimentsioak batzen dituztela: ekonomikoa, soziala eta ingurumenekoa». Haien bidez, Milurtekoko Garapen Helburuei ekin nahi zaie berriro, eta «horiek lortu ez zutena lortu nahi da» (milurtekokoekin alderatuta, oraingo helburuek ingurumen-arazoetara zabaldu dute ekintzen esparrua). Azken esaldi hori oso esanguratsua da, eta aurrean dugun erronkarik handiena den horri eusteko orduan Nazio Batuen Erakundeak berak duen ahulezia estrukturalaren seinale.

Garapen iraunkorra hizpide daukagula, funtsezkoa da aldez aurretik zertaz ari garen zehaztea. Hortaz, zer da iraunkortasuna? Definizio asko eta askotarikoak ematen diren arren, guk hauxe lehenesten dugu, heldu nahi dugun lekura heltzeko bidea ematen digulako, hots, gure helbide delako: «Sistema batek ingurunera egokitzeko duen gaitasuna da. Ingurumen-narriaduraren erantzule diren dimentsio ekonomiko eta sozialak jasotzen ditu. Baina ingurumenean eragin zuzenik ez duten alderdi sozioekonomikoak ere jasotzen ditu (enplegua, pentsioak...). Gure gizarteek denboran iraun dezaten beharrezko diren eraldaketak zehaztea du helburu» [2]. Azpimarratzekoa da «ingurunera egokitze» hori. Azken horri helduta, definizio motzago bat ere eman daiteke, kontzeptuaren mamia mantenduz: mugak ezagutu eta onartu beharra; muga biofisikoak, jakina. Eta ez, mugak ez ditugu uste bezain ondo ezagutzen, biodibertsitatearen etengabeko galerak erakusten duen legez.

\section{IRAUNKORTASUNA: URA ARDATZ}

Ingurumena kontuan hartuta, ikuspuntu berritu batetik heldu behar diogu iraunkortasunaren erronkari. Hala, kontzeptu horren ohiko hiru di-

\footnotetext{
1 Testuaren hasieran aipatzen den «Gure mundua eraldatzea: 2030 Agenda Garapen Iraunkorrerako» dokumentutik hartu dira Agendaren gaineko euskarazko aipamenak, hitzez hitz.
} 
mentsioei (gizarte bidezkoa, ingurumen bizigarria, ekonomia osasuntsua) laugarren bat gehitzen zaie: lurraldea, hots, aurreko hiru osagarriok ekintza-planen bidez gauzatzen joateko ezinbestekoa den ingurune biofisikoa, gazteluak ez baitira airean eraikitzen. Horra, beraz, hidrologiatik ari garen ikertzaileok iraunkortasunari egin diezaiokegun ekarpenik handiena: ura eta lurra uztarri berean lotuta han-hemengo lurralde dinamikoak erresiliente egiteko bidean ezagutza sortzea eta zabaltzea, hartu behar diren erabakiak ezagutzan oinarrituak izan daitezen.

Horren haritik, gogoan hartzekoa da NBEren idazkari orokorrak 2002. urtean Johannesburgeko Lurraren II. Gailurrean esandakoa, hots, iraunkortasuna lortzeko 5 erronka zirela ezinbestekoak, planetako «leku guztietan» erdiestekoak: biodibertsitatea, ura, energia, nekazaritza eta osasuna (BUENO, edo WEHAB, ingelesez) [3]. Artikulu honetan, ura hartuko dugu ardatz, naturak eskaintzen dizkigun bestelako zerbitzu ekosistemikoen lokarria izateaz gain zerbitzu hidrologikoak berak ere pentsamoldera ekarrita.

Handik urtebetera, 2003an, NBEk zera zioen «Ura denontzat, ura bizitzarentzat» txostenean [4]: «Uraren krisia gai publikoen kudeaketaren krisia da funtsean, gaiok gobernatzeko moduarena». Bestalde, «kudeatzaileen inertzia»ri leporatzen zion ezarritako helburuak bete ez izana (lehen Milurtekoko Garapen Helburuez esandakoa bera), nonbait paradigma berriak zabaltzeko oztopo bihurtzen delako inertzia, eta hori oso da kontuan hartzekoa gaur egunean ere. Urari lotuta munduan sortu diren arazoak - asko eta askotarikoak - konpontzeko, erronka batzuk zehazten zituen txostenak, bi ataletan: ongizateari lotuak eta kudeaketari lotuak. Azken horiek dira orain guretzat helduleku.

Izan ere, uholde eta lehorteen arriskuei aurre egiteko ohikoak izaten diren neurriez gain, «ura ibai-arroaren esparruan kudeatu beharra» eskatzen zuen, «uraren funtzio guztiak barne hartuta», ura bera «iraunkortasunaren ardatz» gisa jarriz. Beste era batera esanda, ibaia ondorioa eta ibaiarroa kausa izanda aldatu beharra dugu, eta gaurko ibai-ikuspegiaren ordez arro-ikuspegia ezarri [5-6]. Funtsezkoa da ideia hori kudeatzaileen pentsamoldean barneratzea (iparraldean zein hegoaldean, ekialdean zein mendebaldean), gerora begira han-hemen izan daitezkeen aldaketa-eszenatokien aurrean lurralde eta gizarte erresilienteak izan nahi baditugu behinik behin. Hortaz, ibai-arroa (ura + lurra) oinarrizko unitate biofisiko bihurtzen da lurralde-antolamenduan, eta lurralde osoa ikuspuntu hidrologikotik antolatzea eskatzen du (1. irudia).

UNESCOren World Water Assessment Programme (WWAP) programak funtsezko zeharkako gaitzat hartzen du ura («water as a key crosscutting»), 2030 Agendako helburuak lortzeko bide gisa [4]. Erakunde berak Europar Batasunaren Water Europe programarekin batera argitara 
emandako txostenean (2019), Europatik bertatik ekiteko hainbat bide zabaltzen ditu, ur-arazoak Europakoak ere badiren seinale [7]. «Erronka global» modura hartzen du ura, baita gaur egungo bestelako erronka batzuekin lotu ere: ekonomia zirkularra, gobernantza, parte-hartzea... Are gehiago, zabaldu egiten du urak dituen loturen katea: ura-lurra-elikadura-energiaklima lokarria lehenesten du Europako baliagaien kudeaketa eraginkorrean. Gizarte ur-adimendunak («Water-Smart Societies») kontzeptua ere bultzatzen du, uraren balioak - asko eta askotarikoak - nabarmentzeko. Baina, hala ere, hidrologo modura hutsunea sumatzen dugu goi-mailako adierazpen horietan, Agendako GIHetan sumatu legez uraren arazoak teknikoak balira bezala agertu ohi direlako, eta ez lurraldearen kudeaketarekin zuzenean lotuta. Hortaz, gogoan dugu Malin Falkenmark hidrologo suediar eta Europako ur-aditu handienetakoak esana: «Ingurumen-politikan, lurra eta ura mundu desberdinetakoak direla kontsideratzen da oraindik ere». Indargune gisa, zera gehitu zuen: «Lurraren erabilera, gehienetan, aldi berean da uraren menpeko eta uraren baldintzatzaile» [8].

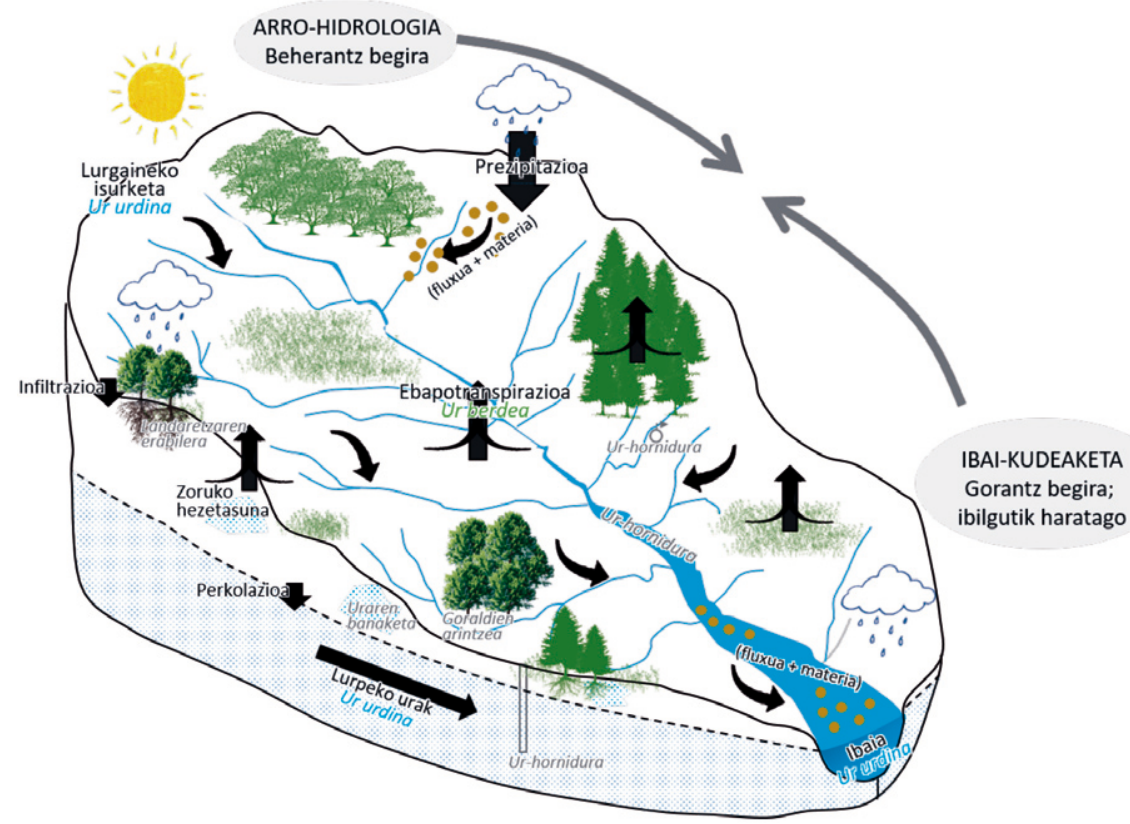

1. irudia. Ibai-arroaren ikuspegi hidrologiko kontzeptuala, klima- eta lurraldealdaketei egokitzeko ezinbestekoa. Ur urdina ibaietan, akuiferoetan, lakuetan eta abarretan dabilen ura da. Ur berdea, berriz, lurzoruan hezetasun moduan biltegiratu eta landareek aldian aldiko erabiltzen duten ura da. 


\section{GOGOETARAKO MOTIBOA}

Ikertzaile gisa, kritiko agertzen gara aurrean ditugun tamainako erronkei eta iraunkortasunari berari heltzeko dugun pentsamolde mugatuaz, inertziak gainditzeko izaten dugun apustu eskasaz. NBE, kudeatzaileen inertzia gaitzesten duelarik, ez dago arrazoi faltan. Are gehiago, Munduko Ekonomia Foroak urte hasieran atera ohi duen «Arrisku Globalen Txostena» izeneko azken dokumentuak [9] jasotzen du egoeraren eboluzioa zertan den, munduan zeharreko elite askotako eragile askori bidali zitzaien inkesta baten bidez jasotako datuei esker. Bost ataletako arriskuak hartzen dira kontuan (gizartea, ingurumena, ekonomia, geopolitika, teknologia), eta bi ikuspegiren arabera zerrendatu: gertatzeko probabilitatea, eta gertatzekotan sortuko luketen inpaktua. Bada, 2007tik aurrerako zerrendei erreparatuta, deigarria gertatzen da kolore berdearen nagusitasuna (ingurumen-arriskua) probabilitatean eta inpaktuan: muturreko gertaera atmosferikoak, naturahondamenak, biodibertsitatearen galera, gizakiak eragindako ingurumenhondamenak, eta, inpaktuen zerrendan buru, bigarrena probabilitateetan, klima-ekintzaren okerra.

Gogoetarako motiboa dugu hori Garapen Iraunkorrerako 2030 Agendako helburuak betetzeko orduan. Ekintza-planetan ez gabiltza fin; naturari egotzitako hondamen asko (uholdeak, luiziak...) neurri handi batean antropikoak dira jatorriz, lurraldea (baso-politiken bidez batez ere) desegoki kudeatzearen ondorio, eta horixe da biodibertsitatearen galeraren kausa ere. Ikertzaile modura, argi dugu klima-aldaketari aurre egiteko ohikoak diren estrategia biak, arintzea eta egokitzea, uztarri berekoak direla, baina arintzea karbonoaren kudeaketaren ikuspuntutik eta mundu mailan bideratu behar bada ere, egokitzea uraren kudeaketarenetik eta ibai-arroen eskalan bideratu behar da, izan Euskal Herrian, izan planetako edozein herrialdetan, betiere lekuan lekuko ezagutzan oinarritutako erabaki estrategikoak - prospektibakoak - hartuta.

Gogoeta-hari horretatik helduko gara gure ekarpen honen mamira: uralurra-klima. Zeharkako ikuspegia da gurea, 2030 Agendako hainbat helburutan sarbide zuzena duena: 6 . helburua (ura: horniketa eta saneamendua, kudeaketa eraginkorra, ur-ekosistemen babesa...), 11. helburua (giza kokaguneak: ingurumenarekiko loturak sendotzea, klima-aldaketaren eta hondamendien aurreko erresilientzia hobetzea...), 13. helburua (klima-aldaketa: egokitzeko ahalmena sendotzea...), 15. helburua (ekosistemak: basoak egoki kudeatzea, degradatutako lurrak berreskuratzea, biodibertsitate-galera gelditzea...). Kontuan hartuko ditugu orobat Agendako helburuetatik barreiatzen diren beste lokarri batzuk, hala nola ura-energia-elikagaiak. 2. irudiak erakusten duen lokarri horretan, argi dago lurraldeari lotutako alderdiak eta, zehatzago esanda, lur-erabilerak kudeatzeko moduari lotutakoak funtsezkoak direla elikadura-segurtasuna bera ere bermatzeko, erresilientziaz eta ur-ekosistemak babestuz jardun nahi badugu. 
Ane Zabaleta, Eñaut Izagirre, Maite Meaurio, Maria Valiente, Jesus Angel Uriarte, Iñaki Antiguedad

a) 2030 AGENDA

a) Helburuak
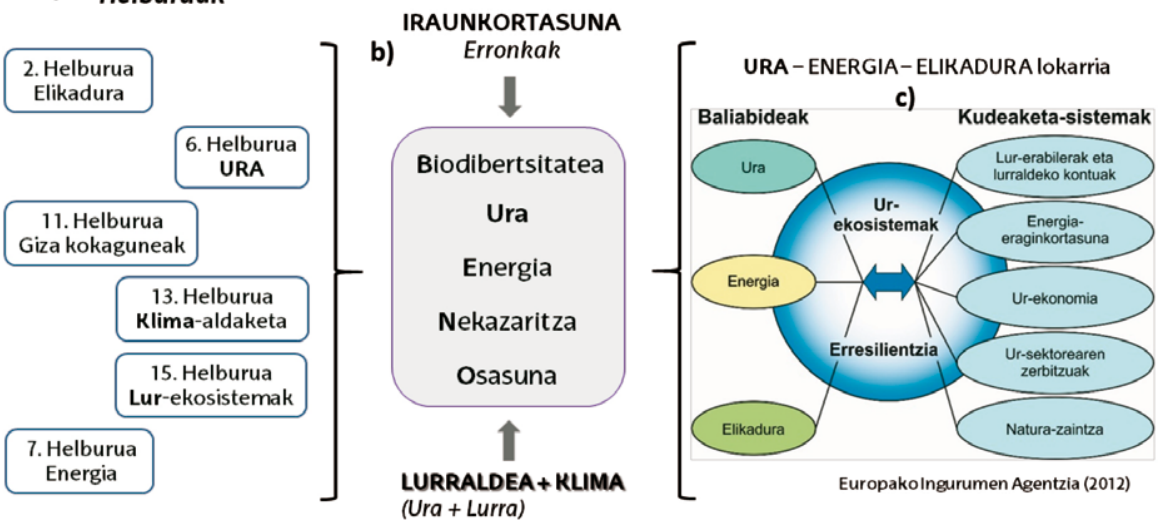

2. irudia. a) Ura 2030 Agendako helburu askoren zeharkako helburua da [1]. b) Iraunkortasunaren 5 zutabe [3]. c) Ura-energia-elikagaiak lokarria (moldatua [10]).

\section{ARINTZEA, EGOKITZEA ETA GARAPEN IRAUNKORRA: HELBURU-GATAZKAK ETA SINERGIAK}

Klima-aldaketari buruzko gobernuarteko taldearen (Intergovernmental Panel on Climate Change, IPCC) 5. ebaluazio-txostenak egokitzea eta arintzea batera hartuko dituen garapen modu baterako deia egiten du baldin eta garapen iraunkorraren helburua lortuko bada [11]. Horrek politika klimatikoaren bi helburuen sinergiak ustiatzea, helburu-gatazkak minimizatzea eta egokitzearen eta arintzearen arteko lotura instituzionalak garatzea eskatzen du [12]. Arintzearen eta egokitzearen arteko loturak eta helburugatazkak oso argiak dira lurraldearen erabilerei buruz ari garenean, baina badira ikuspegi integratu horretan muga garrantzitsuak: tokiko eskalari lotutako ezagutza falta, batetik, eta tokiko eskalaren eta eskala globalaren arteko helburu-gatazkei eta sinergiei dagokienez ezagutzan dauden arrailak, bestetik [13-14].

Izan ere, klima-aldaketarekin lotutako mundu mailako arintze-politiken oinarriak karbonoa bahitzea eta horri lotuta lurraldea basotzea dira hein handi batean, basotze horrek lurraldea (zentzu zabalenean) egokitzean izan ditzakeen albo-kalteak kontuan izan gabe, hala nola ur-baliabideen murriztea [15-16]. Hala, klima-aldaketa arintzeko politiken helburua karbonoa bahitzea bada, horrek eragin negatiboa izan dezake ura hornitzeko zerbitzuan [17], eta lurraldearen egokitzea zaildu. Ura iraunkortasunaren bidean lehen mailako erronka izanik, oso garrantzitsua da urarekin lotutako zerbitzu ekosistemikoak - hau da, zerbitzu hidrologi- 
koak - jartzea basoberritzean oinarritutako arintze-estrategien ardatzean, karbonoaren biltegiratzea zura eta basotik eratorritako beste produktu batzuk uraren zikloa babesteko diseinatutako estrategien onura gehigarritzat hartuta [18-19].

Lurraldeko prozesu hidrologikoak - hala nola ebapotranspirazioa edo lurgaineko eta lurpeko uren banaketa - uraren kantitatean, kalitatean, kokapenean eta denboran duten eraginaren arabera antolatu ohi dira, eta, beraz, gizakiek erabil ditzaketen uretan (horniduran) duten eraginaren arabera (1. taula) [20-21]. Baina ekosistemek ez dute urik sortzen; aldiz, ura metatu, lekuz mugitu eta izaeraz aldatu egiten dute (materia- eta energia-fluxua), eta, beraz, uraren erregulatzaile gisa duten funtzioa onartuz gero, baliabide hidrologikoen kudeaketa ulertzeko modua aldatuko litzateke, eta horrek lurraldearen kudeaketak zerbitzu hidrologikoak barneratzea erraztuko luke.

1. taula. Arro-mailako prozesu ekohidrologikoek atributu hidrologikoetan duten eragina eta haiek guztiek zerbitzu hidrologikoekin duten erlazioa. Interesekoa den zerbitzu hidrologikoa eta horrekin lotutako atributu nagusia zehazteak kudeatu edo neurtu beharreko prozesua identifikatzen lagundu dezake (moldatua [21]).

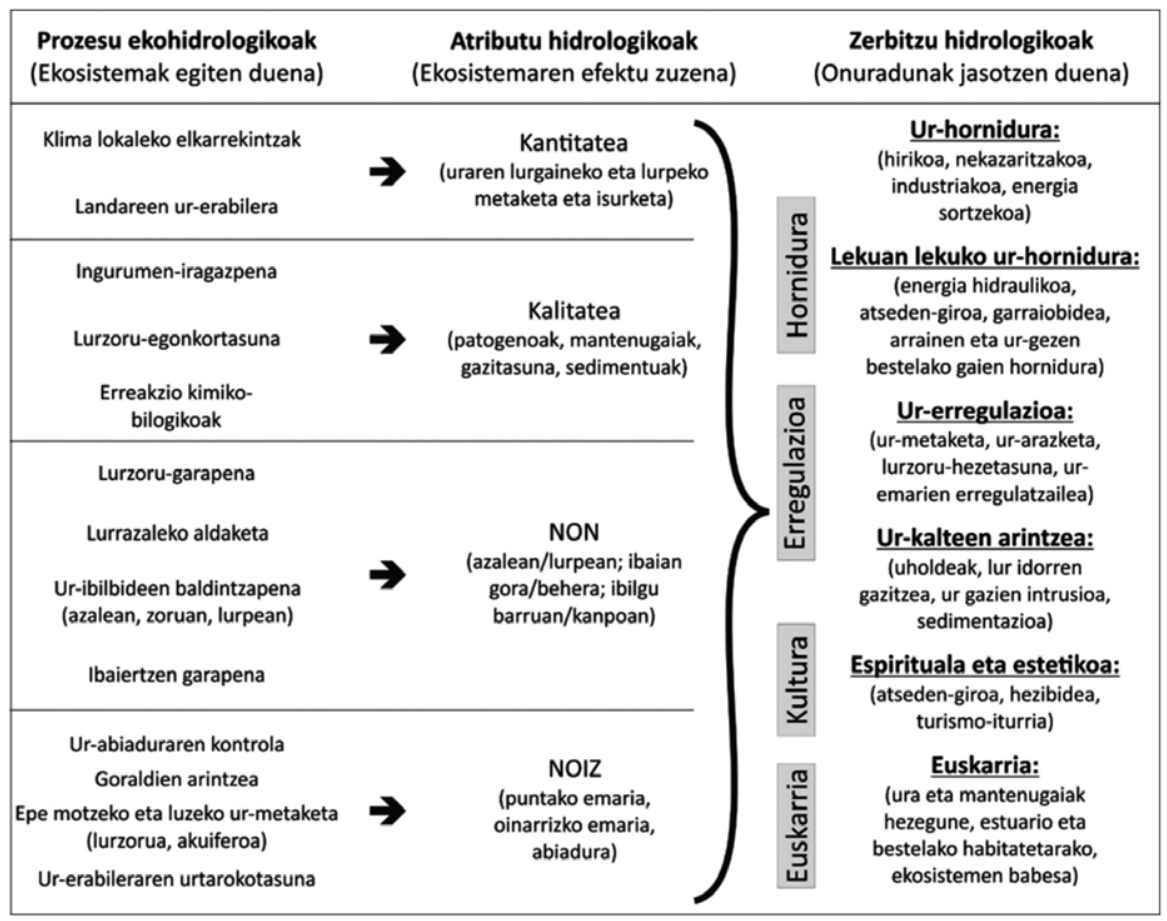


Arintze- eta egokitze-estrategietan eta, beraz, lurraldearen erabilerarekin lotutako politiketan, zerbitzu hidrologikoak lehenesteko ondo ulertu behar da zuhaitz motek, baso-ezaugarriek eta basoak kudeatzeko estrategiek nola eragiten duten ur-fluxuetan. Horretarako, kontuan hartu behar da lur-eremu bakoitzeko ezaugarriak (klimatikoak, geografikoak, geologikoak eta biologikoak) desberdinak direla eta, beraz, behar-beharrezkoa dela lekuan lekuko ezagutza. Bestela esanda: «zuhaitz egokiak leku egokian eta egoki kudeatu behar dira», ikerketaren bidez ebidentziak premisen gainetik jarriz.

\section{EUSKAL HERRIAN LURRA HARTUZ: NONDIK GATOZ?}

Gurera etorrita, eta adibide modura, Gipuzkoako zenbait ibai-arrotan egin ditugun ikerketen emaitzek erakusten dute edozein baso mota egoteak murriztu egiten duela urteko batez besteko ur-emaria (ur-hornidura zerbitzua); murrizketa hori, gainera, handiagoa da urteko prezipitazioa handitu ahala, eta eragin hori nabariagoa da landaketa exotikoak dauden ibai-arroetan [22]. Gainera, beste azterketa batzuen antzera [23-24], azterlan horrek erakusten du basoek ur-goraldiak arintzeko duten potentziala txikia dela (batez ere uholde-mehatxua dagoenean), ohiko premisek diotenaren kontrara; hala ere, lur-estaldurak izan dezakeen eragina aldatu egiten da lekuan lekuko eta urtean urteko aldagai klimatikoekin. Prezipitazio kantitate txikiagoetan, basoek, bereziki landaketa exotikoek, larreek baino ahalmen handiagoa dute ur-goraldiak arintzeko, baina ahalmen hori murriztu egiten da prezipitazioa handitu ahala, eta, prezipitazio altuko urteetan, ur-goren magnitudea murrizteko landaketa exotikoen potentziala txikiagoa da bertako basoena edo larreena baino.

Bada, ordea, kontuan izan beharreko beste eragile bat ere. Bizkaiko Golkoko ehundik gora ibaietako ur-emarien serie historikoekin egindako azterketatik ondorioztatu dugunez [25], azken 6 hamarkadetan (19552015 artean), ur-emarien beheranzko joera orokorra izan da (2. taula). Batez besteko ur-emariek gutxitzeko joera argia dute, eta ur-beheren iraunaldiak, aldiz, luzatzeko joera garbia, urtaroko nahiz urteko eskalan, agorraldia udazkenaren barrenean luzatzen denez gero. Zentzu bereko joerak lurraldearen eremu zabaletan agertzeak adierazten du joera horien kausak erregionala behar duela izan, eta, beraz, lekuan-lekuan egon daitezkeen beste eragile batzuen gainetik, esan dezakegu sistema klimatikoan bertan egon diren aldaketek ibaietako ur-emarietan eragin negatiboa izan dutela. 
2. taula. Bizkaiko Golkoko ibaietako ur-emarien serie historikoen azterketatik urte-sasoi bakoitzerako eratorritako batez besteko ur-emarien joerak azken 20, 40 eta 60 urteetan. Parentesi artean, kontuan hartutako emari-serieen kopurua [25].

\begin{tabular}{|c|c|c|c|c|c|}
\hline $\begin{array}{c}\text { Urteak } \\
\text { (estazio kopurua) }\end{array}$ & UDAZKENA & NEGUA & UDABERRIA & UDA & Oharrak \\
\hline $\begin{array}{c}60 \\
(18)\end{array}$ & negatiboa* & negatiboa* & negatiboa & negatiboa & $\begin{array}{l}\text { Emarien urteko batez besteko joera } \\
\text { udaberriak eta udazkenak } \\
\text { baldintzatzen dute. }\end{array}$ \\
\hline $\begin{array}{c}40 \\
(43)\end{array}$ & negatiboa* & negatiboa** & negatiboa & negatiboa $a^{\star \star \star \star}$ & $\begin{array}{l}\text { Urteko batez besteko emarien joera } \\
\text { udaberriak eta udazkenak } \\
\text { baldintzatzen dute. Emari baxuen (Q20) } \\
\text { goranzko joera, batez ere Aturri- } \\
\text { Landetan eta ardatz pirenaikoan. }\end{array}$ \\
\hline $\begin{array}{c}20 \\
(117)\end{array}$ & negatiboa & positiboa & positiboa & negatiboa*** & $\begin{array}{l}\text { Urteko batez besteko emarien joera } \\
\text { neguak eta udaberriak baldintzatzen } \\
\text { dute. Emari baxuen (Q20) beheranzko } \\
\text { joera, udaberrian batez ere, eta } \\
\text { neguan. }\end{array}$ \\
\hline ( & ndak & intauria & irinioetak & irdatza & xorik gabe, lurralde osoa \\
\hline
\end{tabular}

Hala ere, azken denboraldian (20 urte; 1995-2015 artean), aldaketa batzuk ageri dira aipatutako joera horietan, neguko eta udaberriko ur-emarietan goranzko joera antzeman baita. Beraz, epe luzeko joeraren barnean badira zenbait denboraldi laburragoak zeinetan ur-emarien joerak aldatu eta epe luzeko eboluzioak markatzen duen horretatik aldentzen baitira. Hori horrela izanik, plangintza hidrologikoan, betiere lurraldekoarekin uztartuta, epe labur-ertaineko joerak aintzat hartu behar dira, baina haratago doazenak - epe luzekoak - ahaztu gabe; hortaz, plangintzak estrategikoa behar du izan, prospektiboa, eta dinamikoa. Are gehiago, Bizkaiko Golkorako eskala erregionalean lortutako emaitzek [25] agerian uzten dute zein garrantzitsua den plangintza hidrologikoan kontuan hartzea urtekoa baino finagoa den denbora-eskala (urtarokoa, hilekoa) eta zabalagoa den denbora-ikuspegia (epe laburra, luzea), batez ere klima-aldaketaren eta lur-erabileren inpaktu hidrologikoak plangintza horretan barneratuko badira, eta hala behar luke.

\section{AURRERA BEGIRAKOA}

Klima-aldaketari buruzko gobernuarteko taldeak (IPCC), zirkulazio globaleko modeloen bitartez, etorkizuneko klima-baldintzen joerei buruzko proiekzioak egiten ditu aldiro [26]. Horretarako, etorkizuneko berotegiefektuko gasen balizko kontzentrazio-ibilbideen (RCP) estimazioak erabiltzen ditu. Dena dela, modeloetatik eratorritako aldagai klimatikoek badute eskala-arazo bat (ehunka kilometroko bereizmena dute), ez baitituzte es- 
Ane Zabaleta, Eñaut Izagirre, Maite Meaurio, Maria Valiente, Jesus Angel Uriarte, Iñaki Antiguedad

kualde-eskalako heterogeneotasunak kontuan hartzen. Horregatik, etorkizuneko proiekzio hidrologikoak egiteko, beharrezkoa da datu horiek lurralde txikiagoko eskala batera ekartzea (downscaling), eta, horretarako, metodologia bat baino gehiago erabil daiteke. Hala, etorkizuneko klima-baldintzak iragartzea, prozesu konplexua izateaz gain, ziurgabetasunez josia dago, eta, ondorioz, XXI. menderako iragartzen diren klima-proiekzioek etorkizunerako hainbat eboluzio desberdin aurreikusten dituzte aldagai klimatiko bakoitzarentzat. Kontuan izan behar da etorkizuneko eredu sozioekonomikoei loturiko berotegi-efektuko gasen isurketen mende egongo dela etorkizuneko klima. Ondorioz, etorkizuneko klima-baldintzek eboluzio ugari izan ditzakete, eta, beraz, haiei lotutako inpaktu hidrologikoak ere tarte zabal bateko aukeren artean egongo dira.

2100 horizontea kontuan hartzen badugu, Euskal Autonomia Erkidegorako egindako proiekzio klimatikoen emaitzek iragartzen dute batez besteko tenperatura $1-4{ }^{\circ} \mathrm{C}$ bitartean igo daitekeela eta batez besteko prezipitazioa, aldiz, \% 5-15 artean jaitsi daiteke, nahiz eta proiekzio batzuen arabera prezipitazioan igoerak ere gerta daitezkeen. Horrek, jakina, aldagai horren proiekzioen ziurgabetasun handia islatzen du. Urte-sasoiei dagokienez, udazkenean ikusten dira aldaketarik nabarienak; izan ere, proiekzioek iragartzen dute prezipitazioa $\% 20$ jaitsi daiteke batez beste [27].

Kliman gertatuko diren aldaketek ur-baliabideei nola eragin diezaieketen aztertzeko ibai-arroaren hidrologia simulatzen duten modeloak (dinamika hidrologikoa simulatzen duten ekuazio multzo batez eraikitako modelo hidrologikoak) aurretik azaldutako proiekzio klimatiko sortekin elikatzen dira. Hala, Zadorra ibai-arroko bi azpi-arrotan aztertu ditugu klima-aldaketak hidrologian izan ditzakeen eraginak, Otxandion (klima atlantiarra) eta Audikanan (klima kontinentalagoa) [25]. Urrunagako eta Uribarri Ganboako urtegiak urez elikatzen dituzte bi arro-buru horiek, eta, beraz, haien azterketak interes gehigarria dauka ur-baliabideen hornidurari dagokionez.

Behin modelo hidrologikoa datu meteorologiko eta hidrologiko errealekin kalibratuta eta baliozkotuta egonda, Meteorologiako Estatu Agentziak (AEMET) eskainitako 16 proiekzio klimatikorekin elikatu da. Proiekzio horiek lortzeko, zirkulazio globaleko 5 modelo (ACCESS1-0, BNU-ESM, CMCC-CESM, MPI-ESM-LR, MPI-ESM-MR), 2 downscaling metodo (batetik, AN, AEMETen analogoen metodoa; bestetik, SDSM metodo estatistikoa) eta 2 RCP (4.5 eta 8.5) erabili dira. Zirkulazio globaleko modelo guztiei ez zaizkie bi downscaling metodoak aplikatu, eta modelo guztiek ez dituzte 2 RCPrentzako proiekzioak egin. 16 proiekzio klimatiko horietatik, 16 proiekzio hidrologiko lortu ziren arro bakoitzerako (3. irudia). Emaitzek erakusten dute batez besteko ur-emariek beherantz egingo dutela XXI. mendean zehar, urtaro guztietan, eta, ondorioz, urteko eskalan ere, joera hori nabarmenagoa da Audikanan Otxandion baino. Salbuespena epe mo- 
tzeko udaberriko (2030 eta 2060 horizonteak) eta neguko (2030 horizontea) proiekzioetan izan daiteke; izan ere, proiekzioetako batzuek emariaren igoerak iragartzen dituzte, aurretik iraganeko epe motzeko (20 urte) emari errealen azterketatik ateratako joerari jarraituz. Bestalde, udazkena da emarien batez besteko beheranzko joera nabariena erakusten duen urte-sasoia, $\% 18$ eta \% 33 arteko jaitsiera izango baita, agorraldiak luzatzen jarraituko duen seinale.

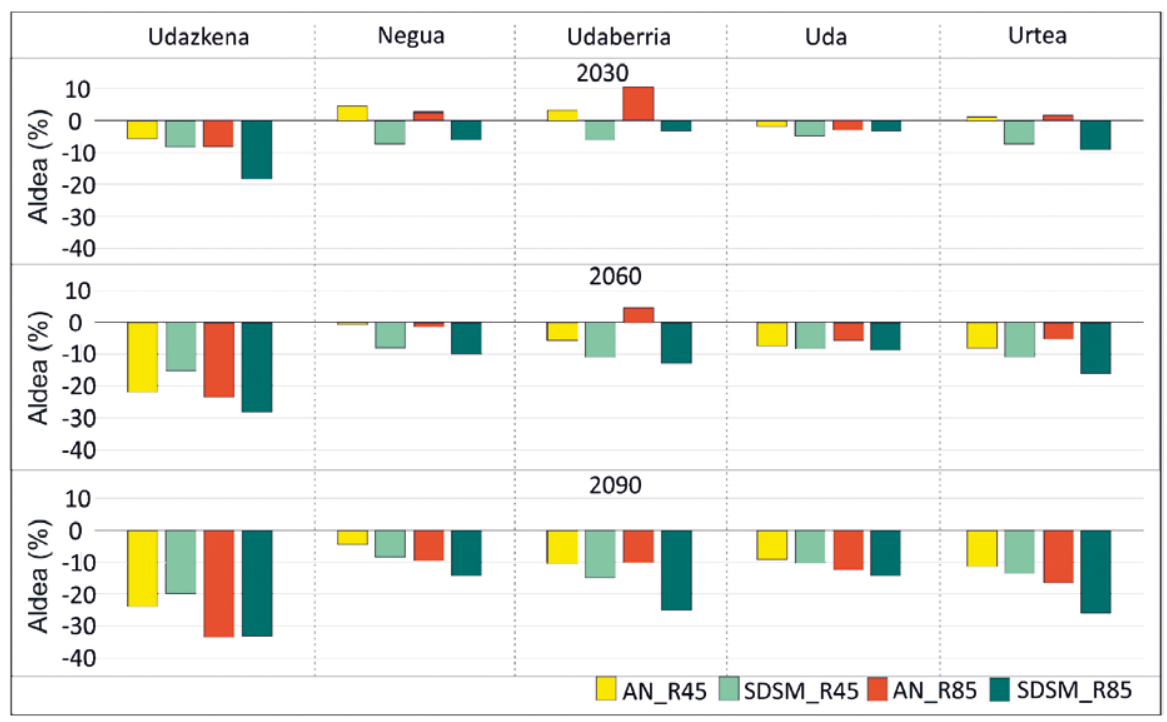

3. irudia. Audikana ibai-arrorako egindako proiekzio hidrologikoetako emariek erreferentziazko aldiko emariekiko duten aldea (ehunekotan), urteka eta urte-sasoika emanda. Hamasei proiekzio hidrologikoen emaitzak lau taldetan taldekatu dira, bi RCP (4.5, irudian 45, eta 8.5, irudian 85) eta downscaling metodoak (AN eta SDSM) kontuan hartuz. Gainera, datuak etorkizuneko hiru horizontetan banatu dira $(2030,2060,2090)$ (moldatua [25]).

Emaitza horiek, kezkagarriak izanik ere gaurko plangintzaren begietatik, kliman gerta daitezkeen aldaketei bakarrik erreparatzen diete, baina ez dituzte kontuan hartzen lurraldearen erabileran egon daitezkeen aldaketak (berezkoak, klima-aldaketak berak eragindakoak, edo planifikatuak). Azken horiek dira, hein handi batean, artikulu honen sarreran aipatutako arro-ikuspegian kontuan hartu beharrekoak eta lurraldeak ur-fluxuak erregulatzeko eta denboran eta espazioan banatzeko duen ahalmenarekin lotuta daudenak (1. irudia, 1. taula). 
Ane Zabaleta, Eñaut Izagirre, Maite Meaurio, Maria Valiente, Jesus Angel Uriarte, Iñaki Antiguedad

\section{KLIMA-ALDAKETATIK HARATAGO: LURRALDEAREN FUNTZIO HIDROLOGIKOA}

1. irudian ikusi bezala, euri-urek, ur-emari bihurtzeko bidean, lurrera iritsi eta lurzorutik igaro behar dute, eta, beraz, ibai-arro bateko lurzoruen ezaugarriek eta bertako landaredi motek eragina dute eraldatze-bide horretan. Hori hala izanik, bada prozesu bat sarri ahaztua izaten bada ere garrantzi handia duena eta plangintza hidrologikoan barneratu beharrekoa: ebapotranspirazioa (ET), hots, lurruntze hutsaz eta, batez ere, landareen transpirazioaz atmosferara itzultzen den ur kantitatea (ur berdea). Horixe da, alde handiz, arro bateko urteko balantze hidrologikoaren (ur-sarreren eta irteeren arteko erlazioa) oinarrizko ekuazioko terminorik ahaztuena:

$$
\begin{gathered}
\mathrm{P}(\text { prezipitazioa })-\mathrm{ET}(\text { ebapotranspirazioa }, \text { ur berdea })= \\
=\mathrm{Q}(\text { lurgaineko zein lurpeko emaria, ur urdina }) .(1 . \text { irudia })
\end{gathered}
$$

Prezipitazioa ezin dugu zuzenean planifikatu, klimak inposatua delako. Ebapotranspirazioa zuzen-zuzenean dago lotuta klimari (prezipitazioa bera, tenperatura, hezetasun atmosferikoa, haizea eta eguzki-erradiazioa), baina baita landarediari (espeziea, adina, dentsitatea) eta lurzoruaren ezaugarriei (sakonera, ur-erretentzio ahalmena) ere, eta, beraz, lurraldearen erabilerari. Hala, ETa planifika dezakegu lurraldea bera horretarako antolatuz, batez ere eskualde zehatzetan, non gerora begirako ur-baliabideak mehatxuan egon daitezkeen.

Landarediaren eta zerbitzu hidrologikoen arteko erlazioa eztabaidagarria bada ere, gehienetan, arro baten basotzeak ibaiko emariak jaistea eragiten du, eta, basoa moztean, igotzea [28-31]. Horretan, garrantzi handia du baso motak ere. Kasurako, ohikoak diren konifero edo eukaliptoen plantazioetatik hostozabaleko basoetara aldatzeak ibai-arroetako ur ekarpena handitu ohi du, bigarren horiek errotazio-denbora luzeagoak izan ohi dituztelako [32]. Izan ere, baso gazteek helduek baino ur gehiago kontsumitzen dute, hots, arroaren ur-balantzeko ebapotranspirazioa handitzen da [19]. Ondorioz, basotzearen eragina neutroa izan daiteke epe luzera, zuhaitzak heldutasunera iristean [33], baldin eta momentu horretan, hazkunde azkarreko plantazioetan gertatu ohi den bezala, zuhaitz horiek moztu eta zuhaitz gazteen ziklo berri bat hasten ez bada.

Gainera, landarediak eta haren kudeaketak eragin zuzena dute lurzoruaren ezaugarrietan (ehundura, egitura, materia organikoaren ehunekoa, sakonera) eta, ondorioz, propietate hidrologikoetan (permeabilitatea, infiltrazioahalmena, ur-erreserba erabilgarria...). Azken horiek lurzoruaren funtzio hidrologikoan eragiten dute, ur-fluxuen banaketan eta erregulazioan; ondorioz, arroaren balantze hidrologikoa baldintzatzen dute, eta, finean, ur-emarien kantitatean, kalitatean, kokapenean eta denboran eragin eta, beraz, zerbitzu hidrologikoak mugatzen dituzte (1. taula) [34-35]. 
Ildo horretatik, lurzoruek mugatzen dute infiltratuko den eta lurzoruan hezetasun moduan geratuko den ur proportzioa (landareek erabil dezaketena). Bestalde, perkolazioa eta lurzoruan zeharreko fluxu- eta biltegiratze-tasak determinatzen dituzte, ur-goraldietan sortutako emariak arinduz eta ura pixkanaka askatuz; hala, zenbait zerbitzu hidrologiko bermatzen dituzte, hala nola ibaien ur-emariak erregulatzea eta oinarrizko emaria mantentzea [36]. Lurzoruek ura biltegiratzeko eta askatzeko duten gaitasuna da, hain zuzen, eskaintzen duten zerbitzu hidrologiko garrantzitsuenetakoa.

Hala, lurzoruaren erabilera aldatzen dugunean, landaretzaren beraren beharrekin lotutako ebapotranspirazioan eragiteaz gain, lurzoruaren ezaugarrietan ere eragiten dugu; haren funtzio hidrologikoetan, alegia. Alde horretatik, gaur egun, ebapotranspirazioa plangintza hidrologikoaren alderdirik ahaztuena den era berean, lurzorua da lurralde-antolamenduaren elementu ahaztuena, biak ala biak ere plangintzan kontuan hartu beharrekoak eta zuzen-zuzenean ur-fluxuen erregulazioan eragiten dutenak.

\section{AZKEN GOGOETA: ZIURGABETASUNAK KUDEATU}

Ziurgabetasunen aroa dugu oraingoa, eta hori gertatzen da iraunkortasuna oinarritzen dugun lau dimentsioetan: soziala, ingurumenekoa, ekonomikoa eta baita lurraldekoa ere, aurreko hirurak gauzatzen diren esparrua den heinean. Dimentsio-esparru horietan gerora begira izan daitezkeen eszenatokiak asko eta askotarikoak dira (klima, pandemiak, migrazioak...), baina gure gizarteak ez dira agertoki horiek behar bezala aurretik antzemateko gai, finean gure ezagutza mugatua eta zatikakoa delako.

Hortaz, nahikoa al da lurraldeko loturen sareaz daukagun ezagutza? Nahikoa ote, etorkizun konplexu posibleetan ekosistemak biziberritu eta ingurumen bizigarriko zerbitzu ekosistemikoak segurtatzeko? Ziurgabetasuna eta konplexutasuna eskutik datoz, eta ikerketa-bide nagusiak auzi horiek argitzera bideratu behar genituzke, haiek egoki kudeatzeko ezagutza sortu eta horren arabera informatutako erabakiak har daitezen, ohiko inertziak gaindituta. Ildo horretan, gogoan dugu lurra-ura-garapenaz Newson-ek zioena: «ezagutzaren balioa kudeaketarako gida gisa» [37].

Klima-aldaketa gurean dugula, ezin dugu lurraldearen geroa antolatu gaur arte heldu den iraganean antolatu den bezala; egokitzeaz ari garela zein arintzeaz ari garela, ezin. Kudeaketa-paradigma aldatu behar dugu [6]. 4. irudiak erakusten du ibai-arroen kudeaketan izan den bilakaera: koordinatu gabeko fase batetik, era guztietako azpiegiturak sakralizatzeko fase tekniko hutsetik pasatuta, gaur indarra hartzen ari den fase estrategiko batera igaro gara, non gobernantzaren (soziohidrologia) eta plangintza integratuaren (lurraldea bere zatien osotasun gisa hartuta) garrantzia aitortu nahi baita, egokitzapen-estrategia baterako bidean. 

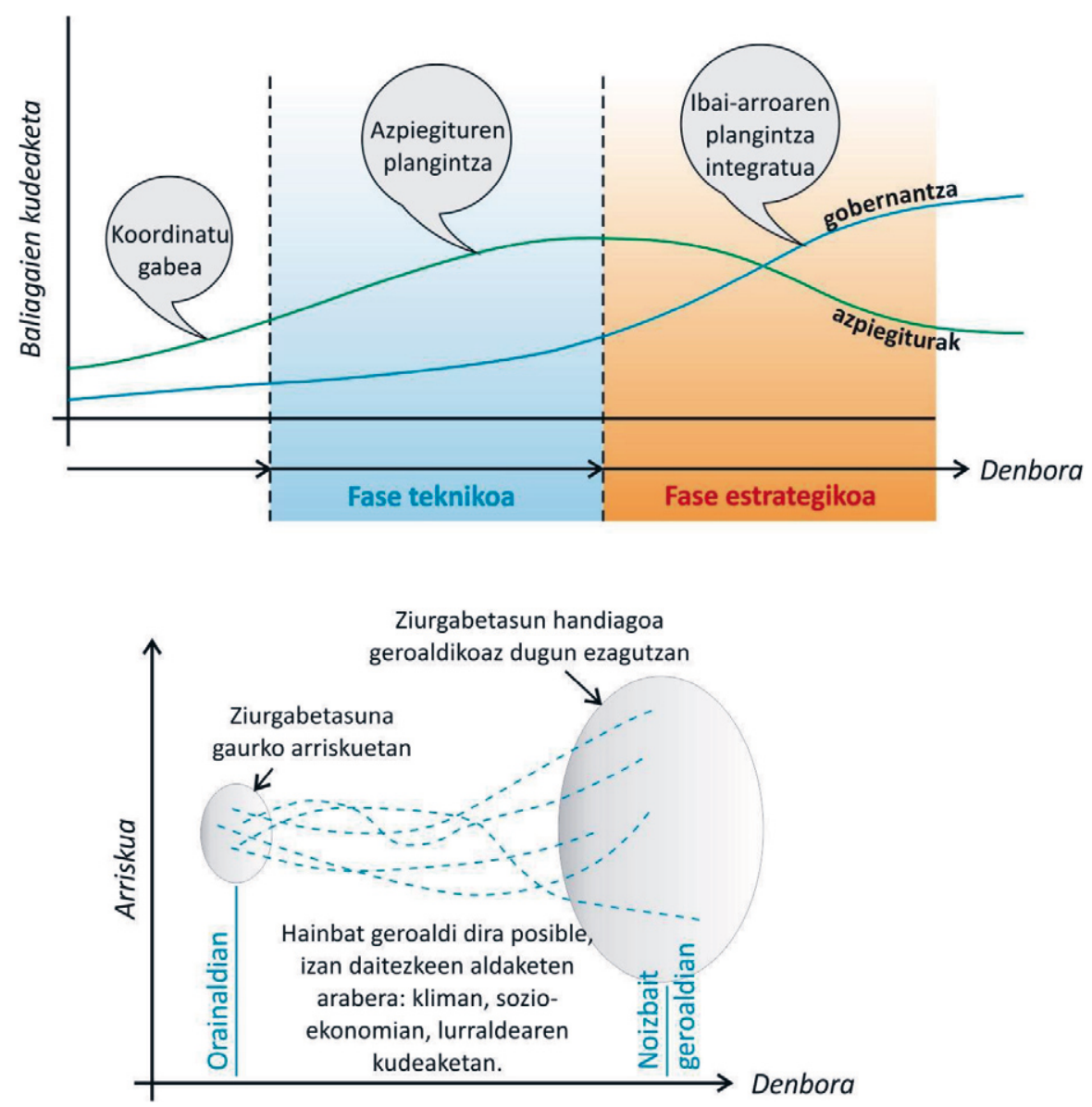

4. irudia. Ibai-arroen kudeaketaren bilakaera denboran (goian). Gerora begirako ziurgabetasun-areagotzea (moldatua [38]).

Irudi berak jasotzen du etorkizunak halabeharrez berekin dakarren ziurgabetasun gero eta handiagoaren ideia [38]: «Etorkizuneko aldaketei aurre egiterakoan, klima-aldaketa barne, arroen plangintza, funtsean, ziurgabetasuna kudeatzeko prozesu gisa ulertu behar da». Ziurgabetasunen kudeaketa da helburu den iraunkortasunerako helbidean dugun erronka handiena. Hortaz, lurralde-dinamika nagusiak birbideratzeko borondate soziopolitikoa behar dugu; gure egin behar ditugu naturak lekuan-lekuan eskaintzen dituen zerbitzu ekosistemikoen mugetara egokituriko garapenereduak, lurra eta ura lurraldearen ardatzean jarrita, planetako herrialde guztietan. 


\section{ESKER ONA}

Artikulu honen egileak Eusko Jaurlaritzak talde finkatu gisa aitortzen duen IT1029-16 Ikerketa Taldekoak dira, bai eta UPV/EHUko UFI11/26 Prestakuntza eta Ikerketa Unitatekoak ere. Eskerrak eman nahi dizkiegu orobat Gipuzkoako Foru Aldundiari eta Eusko Jaurlaritzaren Ingurumen Jarduketarako Sozietate Publikoari (IHOBE), gaiarekin lotutako ikerketa-ildo batzuk jorratzeko emandako dirulaguntzagatik. Maria Valientek MICINNek emandako FPU17/04970 laguntza jaso du.

\section{BIBLIOGRAFIA}

[1] UN General Assembly. 2015. Transforming Our World: The 2030 Agenda for Sustainable Development. A/RES/70/1, UN, New York. Sarean: https:// www.refworld.org/docid/57b6e3e44.html [2020ko urriaren 2an].

[2] BERMEJO, R. 2005. La gran transición hacia la sostenibilidad: Principios y estrategias de economía sostenible. Catarata, Madril.

[3] UN WEHAB Working Group. 2002. A Framework for Action on Health and the Environment. UN, New York.

[4] UN World Water Assessment Programme. 2003. Water for People, Water for Life: A joint report by the 23 UN agencies concerned with freshwater. UNESCO Pub. eta Berghahn Books, New York.

[5] ANTIGUEDAD, I. eta ZABALETA, A. 2016. «Ibai-arroa, ura ulertzeko esparrua». Non: Montesinos, L. (Eds.), Ura materia gisa, 33-36. Cristina Enea Fundazioa, Donostia.

[6] ANTIGUEDAD, I. eta ZABALETA, A. 2018. «El río, consecuencia de su cuenca. La cuenca como unidad básica para la adaptación». Non: Díez, J.R. eta Ibisate, A. (Eds.), Retos y experiencias de restauración fluvial en el ámbito de la Red Natura 2000, 89-106. Eusko Jaurlaritzaren Argitalpen Zerbitzu Nagusia, Donostia.

[7] EU Water Europe. 2019. Water in the 2030 Agenda for Sustainable Development: How Can Europe Act?. Water Europe Pub. eta UNESCO Pub., Brusela.

[8] FALKENMARK, M. 2007. «Society's interaction with the water cycle: a conceptual framework for a more holistic approach». Hydrological Sciences Journal, 42(4), 451-466. doi: 10.1080/02626669709492046.

[9] WEF. 2020. The Global Risks Report 2020. World Economic Forum, Davos.

[10] EEA - European Environment Agency. 2012. European waters - current status and future challenges. EEA, Copenhagen.

[11] DENTON, F., WILBANKS, T.J., ABEYSINGHE, A.C., BURTON, I., GAO, Q., LEMOS, M.C., MASUI, T., O'BRIEN, K.L., eta WARNER, K. 2014. «Climate-resilient pathways: adaptation, mitigation, and sustainable development». Non: Field, C.B., Barros, V.R., (...) eta White, L.L. (Eds.), 
Ane Zabaleta, Eñaut Izagirre, Maite Meaurio, Maria Valiente, Jesus Angel Uriarte, Iñaki Antiguedad

Climate Change 2014: Impacts, Adaptation, and Vulnerability. Part A: Global and Sectoral Aspects. Contribution of Working Group II to the Fifth Assessment Report of the Intergovernmental Panel on Climate Change, 11011131. Cambridge University Press, Cambridge eta New York.

[12] SWART, R. eta RAES, F. 2007. «Making integration of adaptation and mitigation work: mainstreaming into sustainable development policies?». Climate Policy, 7, 288-303 doi: 10.1080/14693062.2007.9685657.

[13] JONES, R.N., DETTMANN, P., PARK, G., ROGERS, M., eta WHITE, T. 2007. «The relationship between adaptation and mitigation in managing climate change risks: a regional response from North Central Victoria, Australia». Mitigation and Adaptation Strategies for Global Change, 12, 685-712. doi: 10.1007/s11027-007-9094-5.

[14] LOCATELli, B., PAVAGEAU, C., PRAMOVA, E., eta DI GREGORIA, M. 2015a. «Integrating climate change mitigation and adaptation in agriculture and forestry: opportunities and trade-offs». WIREs Climate Change, 6 , 585-598. doi: 10.1002/wcc.357.

[15] RIND, D., GOLDBERG, R., HANSEN, J., ROSENZWEIG, C., eta RUEDY, R. 1990. «Potential evapotranspiration and the likelihood of future drought». Journal of Geophysical Research Atmospheres, 95, 9983-10004. doi: 10.1029/JD095iD07p09983.

[16] LIU, Y., XIAO, J., JU, W., XU, K., ZHOU, Y., eta ZHAO, Y. 2016. «Recent trends in vegetation greenness in China significantly altered annual evapotranspiration and water yield». Environmental Research Letters, 11, 094010, doi: 10.1088/1748-9326/11/9/094010.

[17] JACKSON, R.B., JOBBÁGY, E.G., AVISSAR, R., ROY, S.B., BARRETT, D.J., COOK, C.W., FARLEY, K.A., LE MAITRE, D.C., MCCARL, B.A., eta MURRAY, B.C. 2005. «Trading water for carbon with biological carbon sequestration». Science, 310, 1944-1947. doi: 10.1126/science.1119282.

[18] LOCATELLI, B., CATTERALL, C.P., IMBACH, P., KUMAR, C., LASCO, R., MARÍN-SPIOTTA, E., MERCER, B., POWERS, J.S., SCHWARTZ, N., eta URIARTE, M. 2015b. «Tropical reforestation and climate change: beyond carbon». Restoration Ecology, 23, 337-343. doi: 10.1111/rec.12209.

[19] ELliSON, D., MORRIS, C.E., LOCATELLI, B., SHEIL, D., COHEN, J., MURDIYARSO, D., GUTIERREZ, V., VAN NOORDWIJK, M., CREED, I.F., POKORNY, J., GAVEAU, D., SPRACKLEN, D.V., TOBELLA, A.B., ILSTEDT, U., TEULING, A.J., GEBREHIWOT, S.G., SANDS, D.C., MUYS, B., VERBIST, B., SPRINGGAY, E., SUGANDI, Y., eta SULLIVAN, C.A. 2017. «Trees, forests and water: Cool insights for a hot world». Global Environmental Change, 43, 51-61. doi: 10.1016/j. gloenvcha.2017.01.002.

[20] BRAUMAN, K.A., GRETCHEN, C.D., DUARTE, T.K., eta MOONEY, H.A. 2007. "The nature and value of ecosystem services: an overview highlighting hydrologic services». Annual Review of Environment and Resources, 32, 67-98. doi: 10.1146/annurev.energy.32.031306.102758. 
[21] BRAUMAN, K.A. 2015. «Hydrologic ecosystem services: linking ecohydrologic processes to human well-being in water research and watershed management». WIREs Water, 2, 345-358. doi: 10.1002/wat2.1081.

[22] ZABALETA, A., GARMENDIA, E., MARIEL, P., TAMAYO, I., eta ANTIGUEDAD, I. 2018. "Land cover effects on hydrologic services under a precipitation gradient». Hydrology and Earth System Sciences, 22(10), 52275241. doi: 10.5194/hess-22-5227-2018.

[23] ROBINSON, M., COGNARD-PLANCQ, A.-L., COSANDEY, C., DAVID, J., DURAND, P., FÜHRER, H.-W., HALL, R., HENDRIQUES, M.O., MARC, V., MCCARTHY, R., MCDONNELL, M., MARTIN, C., NISBET, T., O'DEA, P., RODGERS, M., eta ZOLLNER, A. 2003. «Studies of the impact of forests on peak flows and baseflows: a European perspective». Forest Ecology and Management, 186(1-3), 85-97. doi: 10.1016/S0378-1127(03)00238-X.

[24] CARRICK, J., BIN ABDUL RAHIM, M.S.A., ADJEI, C., ASHRAA KALEE, H.H.H., BANKS, S.J., BOLAM, F.C., CAMPOS LUNA, I.M., CLARK, B., COWTON, J., DOMINGOS, I.F.N., GOLICHA, D.D., GUPTA, G., GRAINGER, M., HASANALIYEVA, G., HODGSON, D.J., LÓPEZ-CAPEL, E., MAGISTRALI, A.J., MERRELL, I.G., OIKEH, I., OTHMAN, M.S., RANATHUNGA MUDIYANSELAGE, T.K.R., SAMUEL, C.W.C., SUFAR, E.K., WATSON, P.A., ZAKARIA, N.N.A.B., eta STEWART, G. 2018. «Is Planting Trees the Solution to Reducing Flood Risks?». Journal of Flood Risk Management, 12(S2), 1-10. doi: 10.1111/ jfr3.12484.

[25] ZABALETA, A., MEAURIO, M., MORALES, T., EPELDE, A., URIARTE, J. eta ANTIGUEDAD, I. 2016. Vulnerabilidad hídrica: de las tendencias del pasado reciente a las del futuro (adaptación a nuevos escenarios hidrológicos). IHOBE, Ingurumen Jarduketarako Sozietate Publikoa, Eusko Jaurlaritzaren Ingurugiro, Lurralde Antolamendu eta Etxebizitza Saila, Bilbo. Sarean: https://www.euskadi.eus/gobierno-vasco/-/documentacion/2017/klimatek-eghilur-vulnerabilidad-hidrica-de-las-tendencias-del-pasado-recientea-las-del-futuro/ [2020ko urriaren 2an].

[26] RANDALL, D.A., WOOD, R.A., BONY, S., COLMAN, R., FICHEFET, T., FYFE, J., KATTSOV, V., PITMAN, A., SHUKLA, J., SRINIVASAN, J., STOUFFER, R.J., SUMI, A., eta TAYLOR, K.E. 2007. «Climate Models and Their Evaluation». Non: Solomon, S., Qin, D., (...) eta Miller, H.L. (Eds.), Climate Change 2007: The Physical Science Basis. Contribution of Working Group I to the Fourth Assessment Report of the Intergovernmental Panel on Climate Change, 589-662. Cambridge University Press, Cambridge eta New York.

[27] BRUNET, B., CASADO, M.J., DE CASTRO, M., GALÁN, P., LÓPEZ, J.A., MARTÍN, J.M., PASTOR, A., PETISCO, E., RAMOS, P., RIBALAYGUA, J., RODRÍGUEZ, E., SANZ, I. eta TORRES, L. 2009. Generación de Escenarios Regionalizados de Cambio Climático para España. Spanish Me- 
Ane Zabaleta, Eñaut Izagirre, Maite Meaurio, Maria Valiente, Jesus Angel Uriarte, Iñaki Antiguedad

teorological Agency (AEMET). Sarean: http://www.aemet.es/es/portal/serviciosclimaticos/cambio_climat [2020ko urriaren 2an].

[28] BOSCH, J. eta HEWLETT, J. 1982. «A review of catchment experiment to determine the effect of vegetation changes on water yield and evapotranspiration». Journal of Hydrology, 55, 3-23. doi: 10.1016/0022-1694(82)90117-2.

[29] ANDRÉASSIAN, V. 2004. «Waters and forests: from historical controversy to scientific debate». Journal of Hydrology, 291, 1-27. doi: 10.1016/j. jhydrol.2003.12.015.

[30] FARLEY, K., JOBBÁGY, E. eta JACKSON, R. 2005. «Effect of afforestation on water yield: a global synthesis with implications for policy». Global Change Biology, 11(10), 1565-1576. doi: 10.1111/j.1365-2486.2005.01011.x.

[31] LI, Q., WEI, X., ZHANG, M., LIU, W., FAN, H., ZHOU, G., GILES-HANSEN, K., LIU, S. eta WANG, Y. 2017. «Forest cover change and water yield in large forested watersheds: A global synthetic assessment». Ecohydrology, 10(4), e1838. doi: 10.1002/eco.1838.

[32] HIRSCH, F., CLARK, D. eta VIHERVAARA, P. 2011. Payments for Forest-related Ecosystem Services: What Role for a Green Economy? UN, Geneva.

[33] SCOTT, D.F. eta PRINSLOO, F.W. 2008. «Longer-term effects of pine and eucalypt plantations on streamflow». Water Resources Research, 44(7), W00A8. doi: 10.1029/2007WR006781.

[34] SCANLON, B.R., REEDY, R.C., STONESTROM, D.A., PRUDIC, D.E. eta DENNEHY, K.F. 2005. «Impact of land use and land cover change on groundwater recharge and quality in the southwestern US». Global Change Biology, 11(10), 1577-1593. doi: 10.1111/j.1365-2486.2005.01026.x.

[35] ELFERT, S. eta BORMANN, H., 2010. «Simulated impact of past and possible future land use changes on the hydrological response of the Northern German lowland Hunte catchment». Journal of Hydrology, 383(3-4), 245255. doi: 10.1016/j.jhydrol.2009.12.040.

[36] DOMINATI, E.J., PATTERSON, M.G. eta MACKAY, A.D. 2010. «A framework for classifying and quantifying the natural capital and ecosystem services of soils». Ecological Economics, 69(9), 1858-1868. doi: 10.1016/j. ecolecon.2010.05.002.

[37] NEWSON, M. 1992. Land, Water and Development: Sustainable Management of River Basin Systems. Routledge Inc., London.

[38] PEGRAM, G., LI, Y., LE QUESNE, T., SPEED, R., LI, J. eta SHEN, F. 2013. River Basin Planning: Principles, Procedures and Approaches for Strategic Basin Planning. UNESCO, Paris. 